\title{
Enzyme immunoassays with special reference to ELISA techniques
}

\author{
A. VOLLER, A. BARTLETT, AND D. E. BIDWELL \\ From the Department of Clinical Tropical Medicine, London School of Hygiene and Tropical Medicine, \\ Keppel Street, London WCI and Nuffield Laboratories of Comparative Medicine, Zoological Society \\ of London, Regent's Park, London NWI, UK
}

SUMMARY In this review outlines are given of various types of enzyme immunoassays. The applications of such enzyme immunoassays, especially ELISA, are dealt with in detail. It is concluded that these techniques have high sensitivity and will be suitable in due course as routine laboratory tests.

During the last two decades there has been a phenomenal increase in the number and variety of immunodiagnostic tests performed. One of the reasons for this has been the development and perfection of methods which use labelled antigens or antibodies, resulting in tests with very high levels of sensitivity and specificity. Fluorescent labels have been attached to antibodies, and these conjugates are very useful for the rapid identification of organisms responsible for infectious diseases as well as for the measurement of antibody levels especially in infectious and auto-immune diseases (Nairn, 1976). Isotopes were found to be suitable, especially as labels on antigens, and radioimmunoassay (RIA) has become the method of choice for sensitive assays of both large and small molecular weight substances (Sonksen, 1974). These assays have been of especial value for steroids (Cameron et al., 1975).

However, both immunofluorescence and RIA have their limitations. Immunofluorescence is tedious, time consuming, and not easily automated so it can be used for only small batches of tests. In contrast, RIA is particularly suitable for large-scale operations but the short shelf-life of the reagents, the rather sophisticated expensive equipment, and the strict regulatory controls on the use of isotopes have tended to exclude RIA from many small laboratories. These considerations have led workers to search for alternative labels for antibodies or antigens. Many candidates have been proposed for this role, for example, bacteriophages (Haimovitch et al., 1970), metals (Cais et al., 1977), and free radicals (Leute et $a l .$, 1972) but at present the most promising new

Received for publication 23 February 1978 labels are enzymes. These can be linked to antibodies or antigens such that the complexes have both immunological and enzymatic activity. Degradation by the enzymes of a chromogenic or fluorogenic substrate yields an amplification factor, which enables accurate and sensitive detection of the presence of the enzyme.

Most of the enzyme-immunoassays are analogous to fluorescence or radioimmunoassays in that they involve at least one separation step in which the 'bound' enzyme labelled reagent is separated from the unbound enzyme, enabling measurement of either bound or free activity. This is the basis of all 'heterogeneous enzyme immunoassays', for example, the 'enzyme-linked immunosorbent assay' (ELISA), which will be the main subject of this review. However, one method, the homogeneous enzyme immunoassay (Rubinstein et al., 1972) deserves special mention at the outset.

\section{Homogeneous enzyme immunoassay}

A diagrammatic outline of this type of assay is given in Figure 1. Hapten is labelled with an enzyme such as lysozyme, malate dehydrogenase, or glucose-6phosphate dehydrogenase so that the enzyme retains its activity. However when the hapten reacts with antibody the enzyme activity of the hapten enzyme complex is inhibited. In the test the unknown sample is mixed with the labelled hapten and with specific antibody to the hapten. If there is hapten in the sample it competes with the labelled hapten for the limited amount of antibody. Thus, there is less antibody available to inhibit the enzyme activity of the labelled hapten. This method is the basis of the 


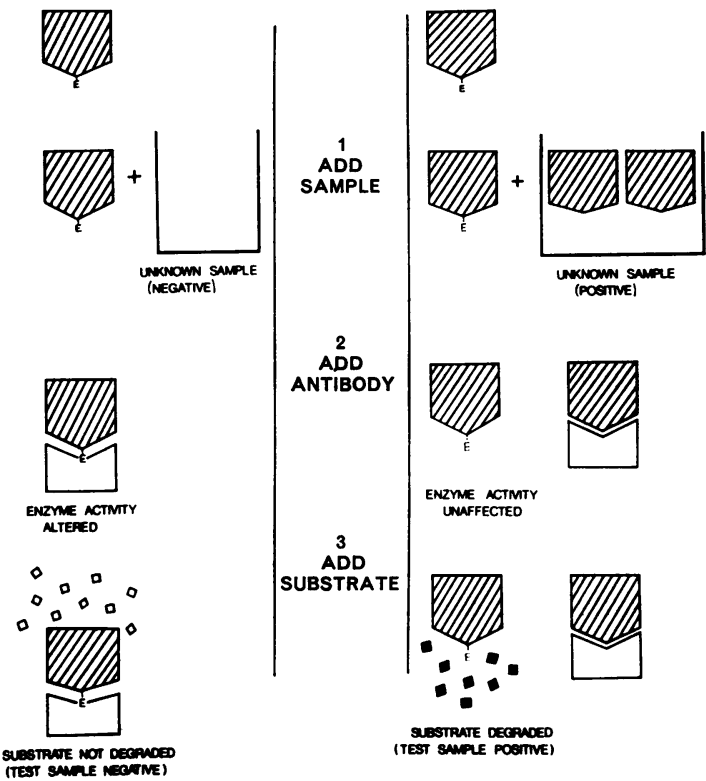

Fig. 1 The homogeneous enzyme immunoassay.

successful EMIT ${ }^{R *}$ system (Bastiani, 1978). It is especially useful for the rapid assay of low molecular weight compounds. Some representative applications of this system are listed in the Table. It is already in use on a large scale for carrying out several thousand thyroxine T4 assays daily in laboratories in the USA (Galen et al., 1976).

Table Some applications of homogeneous enzyme immunoassays

\begin{tabular}{ll}
\hline For drugs of abuse & $\begin{array}{l}\text { Morphine } \\
\text { Amphetamine } \\
\text { Barbiturates }\end{array}$ \\
For cardiovascular drugs & $\begin{array}{l}\text { Digoxin } \\
\text { Propanolol } \\
\text { Quinidine }\end{array}$ \\
& Amitryptyline \\
For antidepressants & $\begin{array}{l}\text { Nortryptyline } \\
\text { Imipramine }\end{array}$ \\
& Methotextrate \\
Chemotherapeutics & Gentamicin \\
& T3 \\
Hormones & T4 \\
& Oestriol \\
& Cortisol \\
\hline
\end{tabular}

Based on material related to EMIT $^{\mathrm{R}}$ by Bastiani (1978).

\section{Heterogeneous enzyme immunoassay}

These are known under a variety of names such as

*Syva Corporation, USA enzyme immunoassay (EIA) (Van Weemen and Schuurs, 1971), enzyme labelled assay (ELA) (Saunders and Wilder, 1974), competitive enzyme linked immunoassay (CELIA) (Yorde et al., 1976), and enzyme-linked immunosorbent assay (ELISA) (Engvall and Perlmann, 1971). The latter is perhaps the most useful term since it identifies the heterogenous enzyme assay yet at the same time clearly differentiates it from the tests which employ antibody-peroxidase conjugates for staining reactions for microscopy.

ELISA tests can be competitive (Fig. 2) for the assay of antigen. Enzyme labelled antigen is mixed with the test sample containing antigen, which competes for a limited amount of antibody. The reacted (bound) antigen is then separated from the free material, and its enzyme activity is estimated by addition of substrate. An alternative method for antigen measurement is the double antibody sandwich technique (Fig. 3). In this modification a solid phase is coated with specific antibody. This is then reacted with the test sample containing antigen, then enzyme labelled specific antibody is added, followed by the enzyme substrate. The 'antigen' in the test sample is 'captured' (Fig. 3-2) and immobilised on to the sensitised solid phase where it can itself then fix the enzyme labelled antibody (Fig. 3-3). This technique is analogous to the immunoradiometric assays

1. ADSORB ANTIBODY TO SURFACE
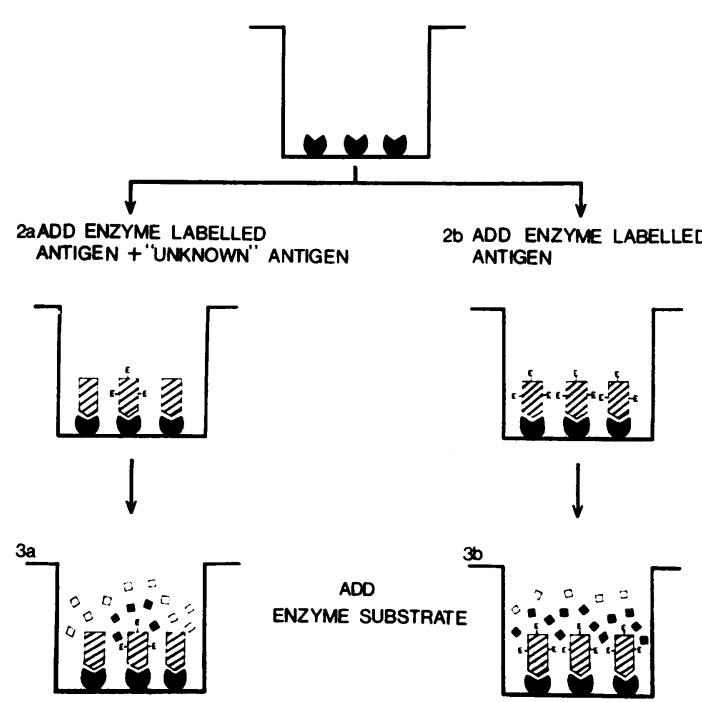

SUBSTRATE HYDROLYSIS = LABELLED [ANTIGEN]

DFFERENCE BETWEEN 3a \& 3b m"UNKNOWN"[ANTIGEN]

Fig. 2 Competitive ELISA for assay of antigen. 
1 ANTIBODY ADSORBED TO PLATE

WASH

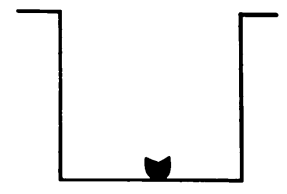

2. TEST SOLUTION CONTAINING ANTIGEN ADDED

WASH

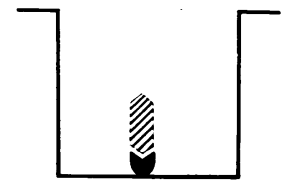

3 ADDENZYME LABELLED SPECIFIC ANTIBODY

WASH

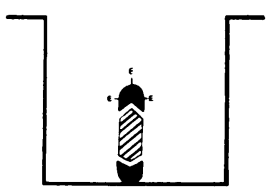

4. ADD ENZYME SUBSTRATE

AMOUNT HMDROLYSIS= AMOUNT ANTIGEN PRESENT

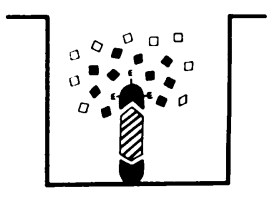

Fig. 3 Double antibody sandwich method of ELISA for assay of antigen.

of Miles and Hales (1968), and has the same sensitivity and specificity for high molecular weight antigens.

ELISA has been used with enthusiasm by workers on infectious diseases, where the need is often for measurement of antibody, and the indirect method of ELISA is particularly applicable (Fig. 4) (Engvall and Perlmann, 1972).

In the indirect method the antigen is immobilised by passive adsorption on to the solid phase. Test sera are then incubated with the solid phase and any antibody in the test sera becomes attached to the antigen on the solid phase. After washing to remove unreacted serum components an antiglobulin enzyme conjugate is added and incubated. This will become attached to any antibody already fixed to the antigen. Washing again removes unreacted material and finally the enzyme substrate is added. Its colour change will be a measure of the amount of the conjugate fixed, which is itself proportional to the antibody level in the test sample.

Various other modifications of ELISA have been used, and these will be illustrated and discussed very briefly. For example, Fig. 5 shows a system where the second antibody used in the double antibody sandwich method is from a different species, and this is then reacted with an anti-immunoglobulinenzyme conjugate. The advantage of this is that it avoids the labelling of the specific antibody, which may be in short supply and of low potency. This same method can be used to assay antibody (in step 3) where only an impure antigen is available; the specific reactive antigens are selected by the antibody immobilised on the solid phase.

In Fig. 6 another assay for antigen is illustrated. Plates are coated with the specific antigen and these are then incubated with a mixture of reference antibody and the test sample. If there is no antigen in the test sample the reference antibody becomes fixed to the antigen sensitised surface. If there is antigen in the test solution this combines with the reference antibody, which cannot then react with the sensitised solid phase. The amount of antibody attached is then indicated by an enzyme labelled antiglobulin conjugate and enzyme substrate. The amount of inhibition of substrate degradation in the test sample (as compared with the reference system) is proportional to the amount of antigen in the test system.

In all these methods passive adsorption to the solid phase can be used in the first step. Adsorption of other reagents can be prevented by inclusion of

1 ANTIGEN ADSORBED TO PLATE

WASH

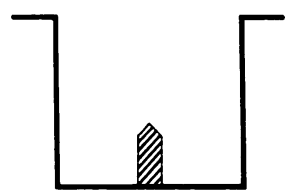

2 ADD SERUM: ANY SPECIFIC ANTIBOOY ATTACHES TO ANTIGEN

WASH
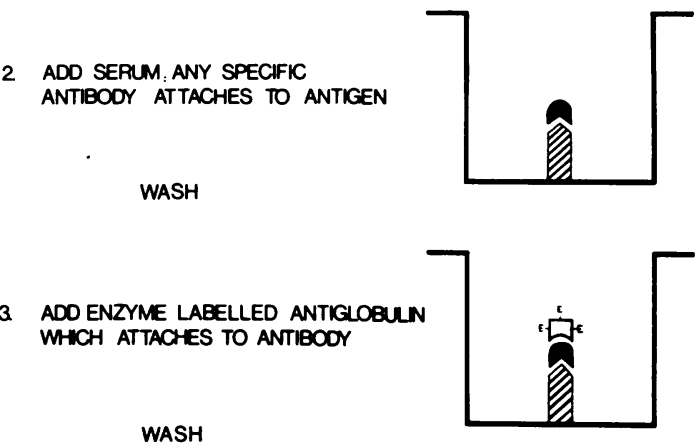

WASH

Fig. 4 The indirect method of ELISA for assay of antibody. 


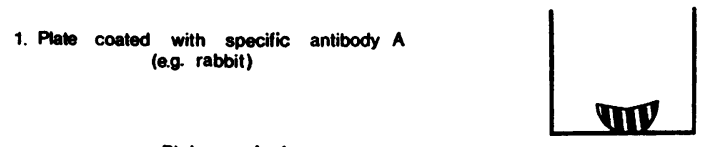

Plate washed

2. Test sample containing antigen reacted

Plate washed

3. Specific antibody B (of different species eg goat) added

Plate washed

4. Enzyme labelled antiB globulin added eg anti goat $\mathrm{kg}$

Plate washed

5. Enzyme substrate added
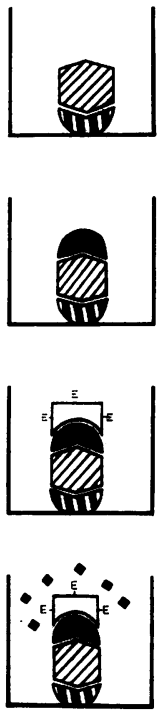

Fig. 5 The double antibody sandwich - antiglobulin ELISA for assay of antigen.

wetting agents in all the subsequent washing and incubation steps. The washing must be sufficient to prevent carry-over of reagents from one step to the next.

\section{Aspects of methodology}

\section{SOLID PHASE}

Although of little interest from an academic viewpoint the format of any diagnostic test determines whether the method is of any practical value in the laboratory. During the last few years a variety of solid phases have been used in enzyme-immunoassay. Particulate materials such as cellulose, agarose, or polyacrylamide with covalently bound antigen or antibody have been used (van Weemen, 1974). However, these all involve centrifugation in the washing or separation steps. The use of a solid phase such as a test tube, bead, or disc simplifies handling procedures, and antigen can be passively adsorbed to such carriers, made of polyvinyl, polypropylene (Engvall and Perlmann, 1971), polycarbonate, glass, or silicone rubber (Hamaguchi et al., 1976a, 1976b). For large-scale work the disposable microtitration plates are particularly convenient (Voller et al., 1974). Dipstick tests are also feasible (Felgner, 1977).

Although various carrier materials can be used, it is essential that each new type is thoroughly tested to find the amount and reproducibility of uptake of the antigen or antibody since these variables influence the results of a test (Bidwell et al., 1977).

\section{ENZYME LABELLED MATERIAL}

In the ELISA method the conjugates usually consist of proteins coupled to enzymes. The coupling has been satisfactorily carried out using glutaraldehyde in either one step (Avrameas, 1969) or two steps (Avrameas and Ternyck, 1971) or by using periodate (Nakane and Kawaoi, 1974). A variety of enzymes have been used, including maleate dehydrogenase, lysozyme, and glucose 6-phosphate dehydrogenase, in the homogeneous assays, and alkaline phosphatase, horse-radish peroxidase, glucose oxidase, and $\beta$-d-galactosidase in ELISA (Avrameas, 1969; Engvall and Perlmann, 1971; Maiolini et al., 1975; Kato et al., 1976b). The main requirements are that the enzyme should have a high turnover number and a substrate which produces stable, soluble, easily measured products on degradation by the enzyme. The enzyme must be reasonably cheap, available in a highly purified form, and suitable for linkage with proteins.
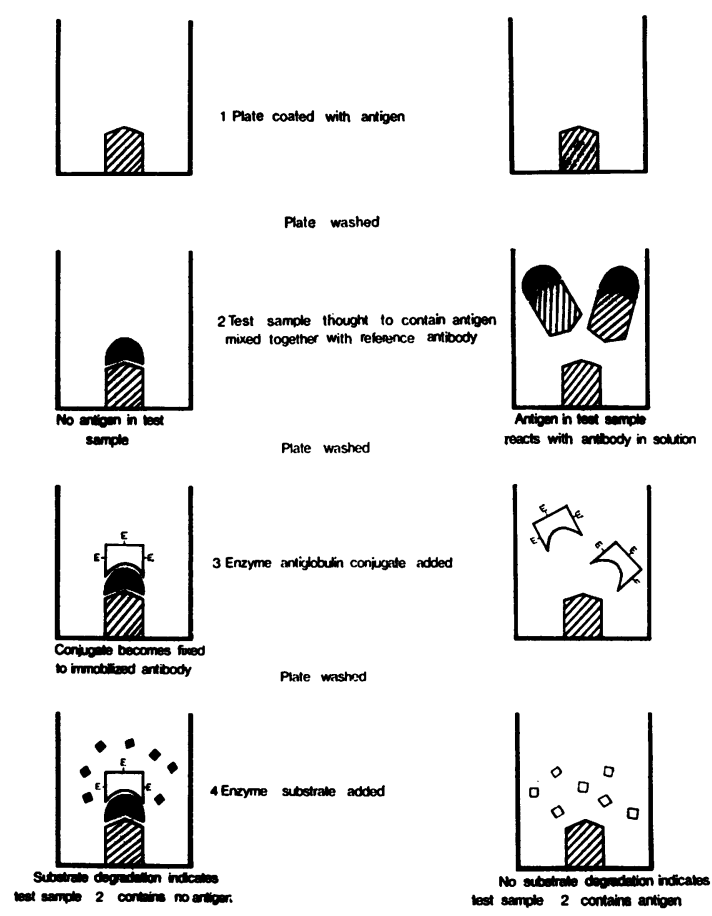

Fig. 6 Competitive antigen modification of the indirect ELISA for assay of antigen. 
The one-step glutaraldehyde method has yielded satisfactory conjugates with alkaline phosphatase and horse-radish peroxidase although the ratio of enzyme to antibody varies somewhat (Avrameas, 1969). The two-step glutaraldehyde method gives conjugates in which enzyme and antibody are present in equal ratio, and this can lead to more sensitive assays (van Weemen and Schuurs, 1974). The periodate method (Nakane and Kawaoi, 1974) produces a good yield of high molecular weight conjugates, which work well in ELISA, as do the dimaleimide linked conjugates of $\beta$-galactosidase, which have small complexes (Kato et al., 1976b).

Substrates are usually chosen to give a coloured product following enzymic degradation. For visually read ELISA tests an insoluble or partially insoluble product may be acceptable (for example, 5-aminosalicylic acid (5AS) or diaminobenzidine (DAB) for peroxidase conjugates). However for all quantitative ELISA tests the substrate product must be soluble. Ortho-phenylene-diamine is suitable for use with peroxidase conjugates although it is light sensitive and is reputed to have mutagenic properties. For alkaline phosphatase conjugates para-nitrophenyl phosphate is an excellent substrate. It is safe, readily available in tablet form, and gives a stable yellow product. However, peroxidase is much cheaper than alkaline phosphatase.

Fluorogenic methyl-umbelliferin substrates are highly sensitive but these are not quite so convenıent for routine use.

For detailed considerations of all the above points the reader should consult the excellent review by Schuurs and van Weemen (1977).

\section{CONDITIONS OF TEST}

It is necessary to ascertain the optimum conditions for each stage of the test, for example,

1 optimum concentration of antibody or antigen coating of solid phase;

2 optimum incubation times and temperatures for sample incubation;

3 optimum type of substrate and time of substrate development.

These are best determined by means of a chequer board titration using reference samples. In the case of tests for antigen, a reference sample containing a known amount of the antigen is used. For antibody tests, reference samples of positive and negative sera are employed.

\section{RESULTS}

For some purposes, especially where a yes/no result is all that is required, the results of ELISA tests can be assessed by eye. Visual reading can be made quantitative by testing a series of dilutions of the test sample. An end-point can be established-being that dilution which produces no discernible substrate colour.

Where more precise readings are needed it is necessary to measure the substrate degradation in a spectrophotometer. For antigen assay the value of an unknown is usually read off a standard curve. For antibody assays a reference standard is incubated in the test, and the substrate reaction on that sample is allowed to proceed until it reaches a predetermined value. The reaction in all other samples is stopped after the same length of time.

There is as yet no generally accepted way of expressing the results. A few possible methods are listed below, all relying on optical density readings made with the spectrophotometer.

1 The optical density value at one dilution of the test sample. Comparison with reference + ve and - ve indicates whether or not unknown is positive.

2 A titre equivalent to the reciprocal of the dilution at which the test sample gives an OD the same as the reference negative sample.

3 The ratio of the OD of the test sample to a group of known refeience negatives.

4 The percentile probability of the OD of the test sample being within the range of a predetermined normal (or abnormal) population.

5 The actual concentration of the substance being determined by reference to a standard curve prepared by plotting OD values of a series of reference samples containing different amounts of the substance.

\section{EQUIPMENT}

In its most rudimentary form ELISA can be carried out with only the sensitised plates or tubes and a series of pipettes for addition of the reagents, the results being measured visually. The next stage of sophistication is to use a spectrophotometer. This can be a relatively simple machine, the only requirements being that $(a)$ it can be used to read optical density at the peak absorbance wavelength of the substrate, (b) it can accept microsamples (200$300 \mu \mathrm{l})$, since the cost of the test is related to the volume of reagent used, and (c) readings can be carried out quickly. At present most of the spectrophotometers which are suitable accept a sample which must be transferred from the tube or plate to a microcuvette. However, one machine has been used in which the results are determined while the sample is still in the reaction tube (Leinikki and Passila, 1976). It is hoped that automatic sampling and through-the-plate readers will soon become available.

ELISA consists of a series of additions of reagents 
separated by washing steps. The reagent additions can be accomplished using any of the commercially available dispensers so long as they are accurate. Special washing aspiration machines are already available for microplate ELISA. Fully automatic ELISA machines can be envisaged (Ruitenberg et al., 1977) although they would be justified only by a very high work load.

COMPARISON WITH ISOTOPIC ASSAYS

It has been an article of faith that radioimmunoassays are the most sensitive and reproducible immuno assays (Landon, 1977), and some workers cling to this view in spite of the available evidence which suggests that for assays of large molecular weight substances enzyme immunoassays have the same sensitivity and precision as isotopic assays. However, for assays of small substances the radioimmunoassays are still preferable since the attachment of a label of high molecular weight, such as the enzyme, can influence the reactivity of the molecule more than the small isotope does.

There is a large fund of experience on which radioimmunoassays are based, and that background information has not yet been accumulated for enzyme immunoassays. Perhaps the main advantage of enzyme conjugates will be their stability compared with the short-lived isotopic reagent. This will make the material more readily usable by peripheral laboratories and in areas of the world where isotopes are not available. The health hazards of isotopes to the user of radioimmunoassays has perhaps been over-emphasised in the past. There is little risk in the use of 125I-labelled reagents; however, the levels of radioactivity during the preparation of labelled reagents are potentially dangerous and expert handling is called for. Quite apart from the actual risks of isotopes are the legislative requirements, which can increase the costs to a laboratory, in terms of safety measures, in the use and disposal of such reagents.

At present there is a wider variety of equipment for radioassays, and although this has led to greater convenience in the performance of the tests and interpretation of the results it has meant that radioimmunoassay has become an expensive tool. Enzyme immunoassays could also be developed to the same level of sophistication with automation but they can be used simply and economically without sophisticated equipment.

Any suggestion that enzyme immunoassays might replace radioimmunoassays (Lancet, 1976) invariably elicits a massive response from the proponents of radioimmunoassay, who cannot envisage any alternative to the currently used methods (Ekins, 1976; Watson, 1976).

\section{Uses of ELISA}

\section{ENDOCRINOLOGY}

Initially, workers were attracted by the idea of replacing current RIA tests with ELISA. Since many of the important assays were for hormones this is the area where much of the pioneering ELISA research was done. van Weemen and Schuurs (1971, 1972, 1974 , 1976) set up ELISA for measuring human chorionic gonadotrophin, and these assays were later also developed by Stimson and Sinclair (1974) and Yorde et al. (1976) to the point where the sensitivity approached that of RIA. Detailed evaluations of the HCG, oestrogen, and luteinising hormone assays have been made by van Weemen (1974) and van Weemen and Schuurs (1976), and all interested in this field should consult this comprehensive document. Parallel studies with ELISA on human placental lactogen (Bosch et al., 1975; van Hell et al., 1976; Barbour, 1976; Sadeh et al., 1976) only resulted in assays which were much less sensitive than RIA. Insulin is another large hormone which has been measured successfully by ELISA (Miedema et al., 1972; Ishikawa, 1973; Kato et al., 1975b; Kitagawa and Aikawa, 1976). Thyroid stimulating hormone has also been assayed with accuracy at very low levels (Miyai et al., 1976).

Smaller molecular weight hormones have also been measured, with a high sensitivity, including progesterone (Dray et al., 1975; Gros et al., 1976), oestriol (Bosch et al., 1975; van Hell et al., 1976; Joyce et al., 1977), and cortisol (Comoglio and Celada, 1976; Ogihara et al., 1977). In spite of these research communications we are not aware of any routine clinical employment of these methods at the present time.

\section{ONCOFETAL PROTEINS}

Another area where ELISA appears to offer great practical possibilities is in the measurement of oncofetal proteins, especially in the large-scale screening for alpha-fetal protein (AFP), which is envisaged in the near future. Already accurate double antibody sandwich and competitive sandwich ELISA methods for AFP have been described by several groups of workers (Belanger et al., 1973, 1976; Maiolini and Masseyeff, 1975; Maiolini et al., 1975; Hevey et al., 1976; Masseyeff et al., 1976; Kirkpatrick et al., 1977) and the method is in routine use in Nice, France.

Carcinoembryonic antigen levels are perhaps of less clinical importance at present but there is a growing demand for assays, and ELISA has been successfully used by Engvall and collaborators (Engvall, 1977; Engvall and Carlsson, 1976; Engvall and Perlmann, 1975; Hammarstrom et al., 1975). 


\section{SERUM PROTEINS}

Immunoglobulin $\mathrm{G}$ was first measured using competitive ELISA methods by Engvall and Perlmann (1971), Engvall et al. (1971), and Avrameas and Guilbert (1971). Kato et al. (1975a, 1976a) used the double antibody sandwich method, which together with a fluorogenic substrate resulted in an exceedingly sensitive assay.

It is rather doubtful whether enzyme-immunoassays are justified for IgG since the simpler methods such as radial gel-diffusion or the more rapid nephelometric assays have adequate sensitivity. However only RIA has previously been sensitive enough for IgE measurements so the ELISA developed for IgE by Hoffmann (1973) and by Weltman et al. (1976) could be of considerable practical value. Ferritin and alpha-2-haptoglobin have been assayed by ELISA but with lower sensitivity than with RIA (Miedema et al.,1972; FuccaroDecaens et al., 1974; Boenisch, 1976;) but Bartlett et al. (1976) obtained good correlations between ELISA and existing methods in their studies on factor VIII.

Perhaps one of the most unusual applications of ELISA in serum testing is for the detection of very small amounts of snake venom and of antibodies to the venom (Theakston et al., 1977).

\section{ANTIGENS OF INFECTIOUS AGENTS}

As early as 1972, ELISA was used to measure the toxins on Vibrio cholerae (Holmgren and Svennerholm, 1973) but it was not followed up for bacterial antigens until recently when Carlsson et al. (1976) assayed antigens from brucella, yersinia, and salmonellae, and more recently by Yolken et al. (1977b), who detected Escherichia coli toxins by ELISA.

Rather more attention has been paid to viral antigen detection, and the first practical microplate ELISA system was developed by Wolters et al. (1976, 1977) for the detection of hepatitis B surface antigen. This was commercialised as Hepanostika (Organon Teknika), which several independent groups have found to be at least as sensitive as currently available RIA kits (Vandervelde et al., 1977; Lange et al., 1977; Ukkonen et al., 1977). Specificity and confirmatory controls are essential, and the simple blocking procedure of Kacaki et al. (1977) has provided these in a convenient form.

Halbert and Anken (1977) described a rather similar double antibody sandwich assay for HBsAg, but plastic discs were used instead of microplates (Cordia H, Cordis Laboratories) as the carrier. They too reported high sensitivity together with remarkable stability and reproducibility of the reagents. Work is now progressing on ELISA for hepatitis A, and it appears to be suitable for detection of the virus in faecal material as well as being useful for antibody assay (Duermeyer et al., 1977; Mathiesen et al., 1977). Yolken and associates (1977a) and Scherrer and Bernard (1977) have also used ELISA for detecting viruses in stools; they were interested in the reovirus-like agents of infantile gastroenteritis. They found ELISA to be as good as electron microscopy and obviously more suitable for field use.

There are few other reports of ELISA being used to detect viruses in clinical specimens, but Miranda et al. (1977) indicated that there is considerable promise in detecting herpes simplex virus in such material. The demonstration of antigen may well become more important in other infectious diseases now that sensitive methods are available. An example of this is the work of Warren et al. (1977), who showed that candida antigen could prove of use in indicating invasive candidiasis. Although rather outside the scope of this journal it is of interest that ELISA has rapidly become established as the test of choice for the detection of viruses in trees and plants (Voller et al., 1976a; Clark and Adams, 1977).

\section{ANTIBODIES}

The published literature indicates that the main impact of ELISA has been in the measurement of antibodies. Laboratories involved in this field often have large numbers of samples to test against many different antigens. At present a variety of procedures such as passive haemagglutination, gel diffusion, immunofluorescence, etc. are used and to a lesser extent RIA. There would be a very considerable advantage in having a single method should this prove feasible. Engvall et al. (1971) first showed that antibodies could be measured by indirect ELISA using enzyme-labelled antiglobulins as the indicator. To detect antibody levels in man a single enzymelabelled anti-human immunoglobulin conjugate is suitable for most purposes, although immunoglobulin class specific conjugates such as enzyme-labelled anti-IgG, IgM, or IgA may be needed for particular purposes (Smith et al., 1974; Goldblum et al., 1975). Such reagents are becoming available commercially so that it is not now necessary for the user to carry out his own enzyme-antibody conjugations.

Some of the problems which may be encountered in enzyme immunoassays are illustrated by the results of tests for antibodies to DNA. Pesce $e t$ al. (1974) found that ELISA gave very variable results, and Engvall (1976) showed that solid phase adsorbed material, such as that used in these tests, could give erroneous results since denatured DNA is adsorbed much more than native DNA. Erikson and Ahlstedt (1977) also found in their assessment of ELISA for 
diagnosis of reaginic allergy that the test was not as good at present as the isotopic assay. Lauer and Erlanger (1974) encountered no such problems when they measured antibody to adenosine.

The first large-scale uses of ELISA for antibody quantitation may well be in the area of viral diagnosis and of epidemiological viral screening, for example, to assess antibody levels after vaccination. In 1975 Voller and Bidwell (1975) showed that rubella antibody could be measured by a microplate ELISA and that the results correlated with haemagglutination inhibition; this was confirmed by Gravell et al. (1977). Much more extensive trials of a commercially produced kit (RUBELISA, Microbiological Associates) carried out by O'Beirne (personal communication) show that the ELISA is an efficient, sensitive, and reliable means of measuring antibody to rubella. By use of the appropriate immunoglobulin class specific conjugate it has also been possible to identify the clinically important IgM antibody response (Voller and Bidwell, 1976). Antibodies to cytomegalovirus can be assayed in a similar manner, and the ELISA may be of special use here because it needs so little antigen (Voller and Bidwell, 1976; Castellano et al., 1977; Schmitz et al., 1977; Anderson and Anderson, 1977; Leinikki and Passila, 1977).

The high sensitivity of ELISA has been found to be advantageous in the assay of antibody to herpes simplex virus (Gilman and Docherty, 1977), and with the appropriate antigen it even permits specific diagnosis of herpes type 2 infection (Grauballe and Vestergaard, 1977; Vestergaard and Grauballe, 1977).

Antibody levels to another member of the herpes group, Epstein Barr virus, have also been measured by ELISA (Voller et al., 1976b; Wallen et al., 1977). Given an antigen which can be adsorbed to a solid phase an ELISA antibody detection system could be set up for virtually any viral agent (Voller et al., 1976c; Bidwell et al., 1977).

Problems are more likely to arise in the interpretation of the tests rather than in the mechanics of doing them. Leinikki and Passila (1976) have approached this problem by developing an ELISA system in which the results of test samples are computed and compared automatically with those of reference samples. This permitted very early detection of antibodies to influenza and to mumps. Very early detection of antibodies to rabies by a sensitive ELISA was also reported by Atanasiu et al. (1977) and by Thraenhart and Kuwert (1977), and this could lead to a useful test for assessing vaccine responses.

Carlsson and colleagues $(1972,1975)$ were the first to realise that ELISA could be used in the field of diagnostic bacteriology. They were able to quantitate antibody to Salmonella $\mathrm{O}$ antigens. The lipopolysaccharide antigens were immobilised quite satisfactorily by passive adsorption to the plastic carriers. The sensitivity of ELISA was at least 10fold greater than passive haemagglutination or the Widal test, and was capable of detecting antibody in both IgG and IgM. Later Carlsson et al. (1976) were able clearly to differentiate the antibody response to Brucella abortus and Yersinia enterocolitica and this can be of real value since serological cross reaction between these species has made diagnosis difficult. Holmgren and Svennerholm (1973) found ELISA satisfactory for assaying antibody to Vibrio cholerae. They noted that immunoglobulin class specific (eg, IgG, IgM) antibodies could be measured but that there was interference between them. Jodal et al. (1974) were able to measure both systemic and local antibody responses to $E$. coli and their demonstration of specific antibody in urine suggested that urinary tract infections might be diagnosed by ELISA. Similar methods were also used by Russell et al. (1976) to assay antibodies to streptococcal $M$ protein. There is still a large amount of treponemal serology carried out, and it could be advantageous to replace the present battery of tests by alternatives such as ELISA. Veldkamp and Visser (1975) showed that this is feasible since in their ELISA study all cases of primary and secondary syphilis were detected, as were most latent and congenital infections. Recently Halle et al. (1977) and Herrman et al. (1977) introduced ELISA for detection of antibodies against Rickettsiae and they found it suitable for both clinical and research laboratories. There is growing interest in the measurement of antibodies to mycobacteria from the diagnostic point of view. Nassau et al. (1976) reported on the use of ELISA for detecting antibody to Mycobacterium tuberculosis, and Samuels (personal communication) has adapted it for assaying antibody in leprosy patients.

There is a need for simpler methods for assessing the response to bacterial vaccines such as those used for whooping cough and tetanus. To date the only ELISA work has been done on tetanus antitoxin levels, both competitive and the indirect methods were satisfactory (Habermann and Heller, 1976; Stiffler-Rosenburg and Fey, 1977; Voller et al., 1977a).

The serology of parasitic diseases has attracted much attention in the last few years partly because people have become more aware of these diseases due to their importation into temperate climates and partly because the role of preventive medicine in the tropics is now appreciated. This has led to demands for diagnosis of infections in individuals and for epidemiological assessments of the diseases in 
endemic areas, an application for which ELISA is ideally suited (WHO, 1976a). Malaria, still one of the world's major infections, was studied by Voller $e$ t al. $(1974,1975 \mathrm{a}, 1976 \mathrm{~d})$ in a number of geographical locations using ELISA, and the authors showed that ELISA values reflected the endemicity. Similarly, schistosomiasis can be assessed (Huldt et al., 1975; Bout et al., 1976; Deelder et al., 1977; McLaren et al., 1978). The sensitivity of ELISA is as high as RIA yet the former is much more suitable for use in the tropics (Schinski et al., 1976; Voller et al., 1977b). ELISA also appears to be suitable for the identification of individuals and communities infected with African or American trypanosomiasis (Voller et al., 1975b, 1975c; WHO, 1976b; Ruitenberg and Buys, 1977).

One of the few parasitic diseases endemic in temperate climates in developed countries is toxoplasmosis, and serology is the only practical means of diagnosis. Obviously an enzyme immunoassay could be of value here in completing the battery of TORCH investigations (toxoplasma, rubella, CMV, and herpes) on pregnant women and neonates. The toxoplasma ELISA data so far published compared favourably with the current tests such as immunofluorescence, haemagglutination, and complement fixation, and it gave very reproducible results (Bout et al., 1976; Voller et al., 1976e; Bullock and Walls, 1977; Walls et al., 1977). ELISA has also been used for a variety of other human parasitic infections such as amoebiasis (Bos et al., 1975), hydatid disease (Bout et al., 1976), onchocerciasis and hookworm (Bartlett et al., 1975), leishmaniasis (Hommel, 1976), and trichinosis (Engvall and Ljungstrom, 1975). The virtue of ELISA is that any department running tests can easily set it up for another disease if the appropriate antigen is made available.

Diagnosis of mycotic infections is also heavily dependent on serological tests. Hommel et al. (1976) showed that antibody to aspergillus and candida could be measured by ELISA, but it is perhaps of more diagnostic relevance that circulating candida antigen can also be assayed (Warren et al., 1977).

We are now witnessing the introduction of methods for detecting immune complexes which can be of diagnostic importance, and already ELISA has been used with success for this purpose (Alhstedt et al., 1976; Casali et al., 1977).

The maintenance of public health demands not only the diagnostic testing of people but also the surveillance of diseases in animals. Enzyme assays have been developed to a high level of sophistication for this purpose by Ruitenberg et al. (1976) and by Saunders et al. (1977).

In this review we have attempted to survey the method and some of the applications of enzyme immunoassays. At present few of these are available in convenient form for the clinical laboratory user but it is to be hoped that industry and public health authorities will now take the necessary measures to enable the wider use of these new tools.

\section{References}

Ahlstedt, S., Hanson, L. A., and Wadsworth, C. (1976). A Clq immunosorbent assay compared with thin layer gel filtration for measuring IgG aggregates. Scand. J. Immunol., 5, 293-298.

Anderson, H. K., and Anderson, P. (1977). Detection of specific IgM antibodies in Cytomegalovirus infection with the ELISA technique. Abstract from the 5th Scandinavian Virus Symposium, pp. 15-16.

Atanasiu, P., Savy, V., and Perrin, P. (1977). Rapid detection of rabies antibodies by immunoenzymatic assay. Ann. Microbiol. (Inst. Pasteur), 128A, 489-498.

Avrameas, S. (1969). Coupling of enzymes to proteins with glutaraldehyde. Use of conjugate for detection of antigens and antibodies. Immunochemistry, 6, 43-52.

Avrameas, S., and Guilbert, B. (1971). Dosage enzymoimmunologique de protéines à l'aide d'immunoadsorbents et d'antigène marqués aux enzymes. Compte. Rend. Acad. Sci., 273, 2705-2707.

Avrameas, S., and Ternyck, T. (1971). Peroxidase labelled antibody and Fab conjugates with enhanced intracellular penetration. Immunochemistry, 8, 1175-1179.

Barbour, H. M. (1976). Development of an enzyme immunoassay for human placental lactogen using labelled antibodies. J. immunol. Methods, 11, 15-23.

Bartlett, A., Bidwell, D. E., and Voller, A. (1975). Preliminary studies on the application of enzyme immunoassay in the detection of antibodies in Onchocerciasis. Tropenmed. Parasit., 26, 370-374.

Bartlett, A., Dormandy, K. M., Hawkey, C. M., Stableforth, P., and Voller, A. (1976). Factor-VIII related antigen: measurement by enzyme immunoassay. Brit. med. J., 1, 994-996.

Bastiani, R. (1978). The EMIT ${ }^{\mathrm{R}}$ System. A commercially successful innovation. Proceedings of 2nd $R$. S. First Symposium on Immunoassays. Karger, Basel. (In press.)

Belanger, L., Hamel, D., Dufour, D., and Pouliot, M. (1976). Antibody enzyme immunoassay applied to human $\alpha$-foetoprotein. Clin. Chem., 22, 198-204.

Belanger, L., Sylvestre, C., and Dufour, D. (1973). Enzyme-linked immunoassay for $a$-foetoprotein by competitive and sandwich procedures. Clinica Chimica Acta, 48, 15-18.

Bidwell, D. E., Bartlett, A., and Voller, A. (1977). Enzyme immunoassays for viral diseases. $J$. infect. Dis., Supplement, 136, S274-278.

Boenisch, T. (1976). Improved enzyme immunoassay for trace proteins. Protides of the Biological Fluids, 24, 743-749.

Bos, H. J., van den Eijk, A. A., and Steerenberg, P. A. (1975). Letter. Application of ELISA in the serodiagnosis of amoebiasis. Trans. R. Soc. trop. Med. Hyg., 69, 440.

Bosch, A. M. G., van Hell, H., Brands, J. A. M., van 
Weemen, B. K., and Schuurs, A. H. W. M. (1975). Clinical Chemistry, 21, 1009-1012.

Bout, D., Dugimont, J. C., Farag, H., and Capron, A. (1976). Immunodiagnosis of human parasitic diseases by ELISA. First International Symposium on Immunoenzymatic Techniques INSERM Symposium No. 2, edited by Feldmann et al., pp. 175-182.

Bullock, S. L., and Walls, K. W. (1977). Evaluation of some of the parameters of the ELISA. J. infect. Dis., 136, Supplement, S279-S286.

Cais, M., Dani, S., Eden, Y., Gandolfi, O., Horn, M., Isaacs, E. E., Josephy, Y., Saar, Y., Slovin, E., and Snarsky, L. (1977). Metalloimmunoassay. Nature, 270, 534-535.

Cameron, E. H. D., Hillier, S. G., and Griffiths, K. (1975). Steroid Immunoassays, p. 1. Alpha Omega, Cardiff.

Carlsson, H. E., Lindberg, A. A., and Hammarstrom, S. (1972). Titration of antibodies to Salmonella O antigens by enzyme-linked immunosorbent assay. Infect. Immunity, 6, 703-708.

Carlsson, H. E., Lindberg, A. A., Hammarstrom, S., and Ljunggren, A. (1975). Quantitation of Salmonella O antibodies in human sera by enzyme linked immunosorbent assay (ELISA). Int. Archs. Allergy appl. Immun., 48, 485-494.

Carlsson, H. E., Hurvell, B., and Lindberg, A. A. (1976). ELISA for titration of antibodies against Brucella abortus and Yersinia enterocolitica. Acta Path. Microbiol. Scand., 84, 168-176.

Casali, P., Bossus, A., Carpentier, N. A., and Lambert, P. H. (1977). Solid phase enzyme immunoassay or radioimmunoassay for the detection of immune complexes based on their recognition by conglutininconglutinin binding test. Clin. exp. Immunol., 29, 342-352.

Castellano, G. A., Hazzard, G. T., Madden, D. L., and Sever, J. L. (1977). Comparison of the enzyme linked immunosorbent assay and the indirect haemagglutination test for detection of antibody to cytomegalovirus. J. infect. Dis., 136, Supplement, S337-S340.

Clark, M. F., and Adams, A. N. (1977). Characteristics of the microplate method of enzyme linked immunosorbent assay for the detection of plant viruses. J. gen. Virol., 34, 475-483.

Comoglio, S., and Celada, F. (1976). An immunoenzymatic assay of cortisol using $E$. coli $\beta$-galactosidase as label. J. Immunol. Methods, 10, 161-170.

Deelder, A. M., Ruitenberg, E. J., Kornelis, D., and Steerenberg, P. A. (1977). Schistosoma mansoni: Comparison of the immunoperoxidase techniques, DASS and ELISA for human diagnosis. Exp. Parasit., 41, 133-140.

Dray, F., Andrieu, J. M., and Renaud, F. (1975). A sensitive immunoassay of progesterone using $\beta$-galactosidase as label. Biochim. Biophys. Acta, 403, 131-138.

Duermeyer, W., Veen der Prie, Jud, and Koster, B. (1977). Enzyme immunoassay for hepatitis A. Presented at the 16th Symposium of the European Association for Rapid Laboratory Viral Diagnosis. Amsterdam 6-9 Sept. 1977. (Unpublished.)

Ekins, R. (1976). Correspondence: ELISA - a replace- ment for radioimmunoassay. Lancet, 2, 569.

Engvall, E. (1976). Determination of antibodies to DNA by ELISA. Lancet, 2, 1410.

Engvall, E. (1977). Enzyme linked immunosorbent assay (ELISA). In Biomedical Applications of Immobilized Enzymes and Proteins, edited by T. M. S. Chang, Vol. 2, pp. 87-96. Plenum Press.

Engvall, E., and Carlsson, H. E. (1976). Enzyme linked immunosorbent assay (ELISA). 1st International Symposium of Immunoenzymatic Techniques. INSERM Symposium No. 2, edited by Feldmann et al., pp. $\vec{\circ}$ 135-147. North Holland Publishing Co., Amsterdam.

Engvall, F., Jonsson, K., and Perlmann, P. (1971). ELISA II. Quantitative assay of protein antigen, IgG by means of enzyme labelled antigen and antibody coated tubes. Biochem. Biophys. Acta, 251, 427-434.

Engvall, E., and Ljungstrom, I. (1975). Detection of human antibodies to Trichinella spiralis by enzyme of linked immunosorbent assay (ELISA). Acta path. 그 microbiol. Scand., Section C, 83, 231-237.

Engvall, E., and Perlmann, P. (1971). Enzyme linked immunosorbent assay (ELISA). Quantitative assay of $\vec{c}$ immunoglobulin G. Immunochemistry, 8, 871-874.

Engvall, E., and Perlmann, P. (1972). Enzyme linked immunosorbent assay (ELISA). III. Quantitation of $\vec{v}$ specific antibodies by enzyme-labelled anti-immuno- $\infty$ globulin in antigen coated tubes. J. Immunol., 109, 129-135.

Engvall, E., and Perlmann, P. (1975). ELISA automation. In Microbiology and Immunology, edited by C. G. Heden and T. Illeny, pp. 529-542. Wiley, New York.

Eriksson, N. E., and Ahlstedt, S. (1977). Diagnosis of reaginic allergy with house dust, animal dander and pollen allergens in adult patients. A comparison between ELISA, provocation skin test and RAST for diagnosis of reaginic allergy. Int. Archs. Allergy appl. Immunol., 54, 88-89.

Felgner, P. (1977). Serologic diagnosis of extraintestinal amebiasis: A comparison of stick-ELISA and other immunological tests. Tropenmed. Parasit., 28, 491-493.

Fuccaro-Decaens, C., Meriadec, B., Buffe, D., and Burtin, P. (1974). Etude comparative le dosage radioimmunologique et le dosage enzymoimmunologique, appliqués à la detection de l'alpha-2-H-globuline sérique. Ann. Immunol., 125C, 747-761.

Galen, R. S., Forman, D. W., O'Brien, J. E., and Brown, P. A. (1976). Enzyme multiplied immunoassay. Lancet, 2, 852-853.

Gilman, S. C., and Docherty, J. J. (1977). Detection of antibodies specific for herpes simplex virus in human sera by the enzyme linked immunosorbent assay. $J$. infect. Dis., 136, Supplement, S286-293.

Goldblum, R. M., Ahlstedt, S., Carlsson, B. Hanson, L. A., Jodal, U., Lidin-Janson, G., and Sohlakerlund, A. (1975). Antibody forming cells in human colostrum $\mathscr{\mathcal { S }}$ after oral immunisation. Nature, 257, 797-798.

Grauballe, P. C., and Vestergaard, B. F. (1977). ELISA for Herpes Simplex Virus Type 2 antibodies. Lancet, 2, 1038-1039.

Gravell, M., Dorsett, P. H., Gutenson, O., and Ley, A. C. (1977). Detection of antibody to rubella virus by enzyme linked immunosorbent assay. J. infect. Dis., 
136, Supplement, S300-303.

Gros, C., Petit, O., and Dray, F. (1976). Enzyme immunoassay of progesterone: a new development. In Protides of the Biological Fluids, edited by H. Peeters, 24, 763-766. Pergamon Press, Oxford.

Habermann, E., and Heller, I. (1976). Two enzyme immunoassays of tetanus antibodies using peroxidasecoupled tetanus toxin as tracer. In Protides of the Biological Fluids, edited by H. Peeters, 24, 825-828. Pergamon Press, Oxford.

Haimovitch, J., Horwitz, E., Novik, N., and Sela, M. (1970). Use of protein bacteriophage conjugates for detection and quantification of proteins. Biochem. Biophys. Acta, 207, 125.

Halbert, S. P., and Anken, M. (1977). Detection of hepatitis B surface antigen ( $\mathrm{HBsAg}$ ) with use of alkaline phosphatase labelled antibody to HBsAg. $J$. infect. Dis., 136, Supplement, S318-323.

Halle, S., Dasch, G. A., and Weiss, E. (1977). Sensitive enzyme linked immunosorbent assay for detection of antibodies against Typhus Rickettsiae, Rickettsia prowazekii and Rickettsia typhi. J. clin. Microbiol., 6, 101-110.

Hamaguchi, Y., Kato, K., Fukui, H., Ishikawa, I., Okawa, S., Ishikawa, E., Kobayashi, K., and Karubuma, N. (1976a). Enzyme linked sandwich immunoassay of macromolecular antigen using the rabbit antibody coupled glass rod as a solid phase. Eur. $J$. Biochem., 71, 459-467.

Hamaguchi, Y., Kato, K., Ishikawa, E., Kobayashi, K., and Katunuma, N. (1976b). Enzyme linked sandwich immunoassay of macromolecular antigens using the rabbit antibody-loaded silicone piece as a solid phase. FEBS Letters, 69, 11-14.

Hammarstrom, S., Engvall, E., Johansson, S. G. O., Svensson, S., Sunblad, G., and Goldstein, I. J. (1975). Nature of the tumour associated determinants of CEA. Proc. Nat. Acad. Sci. USA, 72, 1528.

Hevey, R., Bonacker, L. H., and Sparacio, R. (1976). An enzyme immunoassay for the determination of human alpha-fetoprotein. Ist International Symposium on Immunoenzymatic Techniques. INSERM Symposium No. 2, edited by Feldmann et al., pp. 191-198. North Holland Publishing Co., Amsterdam.

Herrman, J. E., Hollingdale, M. R., Collins, M. F., and Vinson, J. W. (1977). Enzyme immunoassay and radioimmuno precipitation tests for the detection of antibodies to Rochalimaea (Rickettsia) quintana. Proc. Soc. exp. Biol. Med., 154, 285-288.

Hoffman, D. R. (1973). Estimation of serum IgE by ELISA. J. Allergy Clin. Immunol., 51, 303-306.

Holmgren, J., and Svennerholm, A. M. (1973). Enzyme linked immunosorbent assays for cholera serology. Infection and Immunity, 7, 759-763.

Hommel, M. (1976). Enzymoimmunoassay in leishmaniasis. Trans. R. Soc. trop. Med. Hyg., 70, 15-16.

Hommel, M., Kien Truong, T., and Bidwell, D. E. (1976). Technique immunoenzymatique (ELISA) appliquée au diagnostic sérologique des candidoses et aspergilloses humaines. La Nouvelle Press Médicale, 5, 2789-2791.

Huldt, G., Lagerquist, B., Phillips, T., Draper, C. C., and Voller, A. (1975). Detection of antibodies in schisto- somiasis by enzyme-linked immunosorbent assay (ELISA). Ann. trop. Med. Parasit., 69, 483-488.

Ishikawa, E. (1973). Enzyme immunoassay of insulin by fluorimetry of the insulin-glucoamylase complex. $J$. Biochem. (Tokyo), 73, 1319-1321.

Jodal, U., Ahlstedt, S., Carlsson, B., Hanson, L. A., Lindberg, U., and Sohl, A. (1974). Local antibodies in childhood urinary tract infection. Int. Arch. Allergy Appl. Immunol., 47, 537-545.

Joyce, B. G., Read, G. F., and Fahmy, D. R. (1977). A specific enzyme immunoassay for progesterone in human plasma. Steroids, 29, 761.

Kacaki, J., Wolters, G., Kuijpers, L., and Schuurs, A. (1977). Specificity control in solid phase enzymeimmunoassay for HBsAg by one step in situ blocking with human anti-HBs. J. clin. Path., 30, 894.

Kato, K., Hamaguchi, Y., Fukui, H., and Ishikawa, E. (1975a). Coupling Fab fragment of rabbit anti-human IgG antibody to $\beta$-D-galactosidase and a highly sensitive immunoassay of human IgG. FEBS Letters, 56, 370.

Kato, K., Hamaguchi, Y., Fukui, H., and Ishikawa, E. (1975b). Enzyme linked immunoassay. 1. Novel method for synthesis of the insulin $\beta$-D-galactosidase conjugate and its applicability for insulin assay. J. Biochem. (Tokyo), 78, 432-425.

Kato, K., Fukui, H., Hamaguchi, Y., and Ishikawa, E. (1976a). Enzyme linked immunoassay. Conjugation of Fab fragment of rabbit IgG with $\beta$-D-galactosidase from $E$. coli and its use for immunoassay. J. immunol., 116, 1554-1560.

Kato, K., Hamaguchi, Y., Fukui, H., and Ishikawa, E. (1976b). Enzyme linked immunosorbent conjugation of rabbit antibody with $\beta$-D-galactosidase. Eur. J. Biochem., 62, 285-287.

Kirkpatrick, A., Wepsic, H. T., and Nakamura, R. M. (1977). Comparison of double antibody RIA with Farr technique RIA and double antibody enzyme immunoassay for alpha feto-protein. Clin. Chem., 23, 50-59.

Kitagawa, T., and Aikawa, T. (1976). Enzyme coupled immunoassay of insulin using a novel coupling reagent. J. Biochem. (Tokyo), 79, 233-236.

Lancet. (1976). Editorial. ELISA a replacement for radioimmunoassay? Lancet, 2, 406-407.

Landon, J. (1977). Enzyme immunoassays: techniques and uses. Nature, 268, 483-484.

Lange, W., Kohler, H., Aprodaca, J., Ott, A., and Sucker, U. (1977). Demonstration of HBs antigen with the Hepanostika test on enzyme immunoassay. Deut. Med. Wochenschr., 102, 1581.

Lauer, R., and Erlanger, B. (1974). An enzyme immunoassay of antibody specific for adenosine using $\beta$ galactosidase. Immunochemistry, 11, 533-536.

Leinikki, P., and Passila, S. (1976). Solid phase antibody assay by means of enzyme conjugated to anti-immunoglobulin. J. clin. Path., 29, 1116-1120.

Leinikki, P., and Passila, S. (1977). Quantitative, semiautomated, enzyme linked immunosorbent assay for viral antibodies. J. infect. Dis., 136, Supplement, S294-299.

Leute, R., Ullman, E. F., and Goldstein, A. (1972). Spin immunoassays of opiate narcotics in urine and saliva. J. Amer. med. Ass., 221, 1231. 
McLaren, M., Draper, C. C., Roberts, J. M., MinterGoedbloed, E., Lighthart, G. S., Teesdale, C. H., Omer, A. H. S., Bartlett, A., and Voller, A. (1978). Studies on ELISA for Schistosoma mansoni infections. Ann. trop. Med. Parasitol. (In press.)

Maiolini, R., and Masseyeff, R. (1975). A sandwich method of enzymoimmunoassay. I. Application to rat and human alpha-fetoprotein. J. immunol. Methods, 8, 223-234.

Maiolini, R., Ferrua, B., and Masseyeff, R. (1975). Enzymoimmunoassay of human alpha-fetoprotein. $J$. immunol. Methods, 6, 355-362.

Masseyeff, R., Maiolini, R., Ferrua, B., and RagimbeauGilli, J. (1976). Quantitation of alpha-fetoprotein by enzyme immunoassay. In Protides of the Biological Fluids, edited by H. Peeters, 24, 605-612. Pergamon Press, Oxford:

Mathiesen, L. R., Feinstone, S. M., Skinhoej, P., and Purcell, R. M. (1977). Enzyme immunoassay for hepatitis A. 12th Meeting of the European Association for the Study of Liver, Kavouri, Greece, Sept. 1977. Abstract 11-4. (Unpublished.)

Miedema, K., Boelhouwer, J., and Otten, J. W. (1972). Determinations of proteins and hormones in serum by an immunoassay with antigen-enzyme conjugates. Clin. Chim. Acta, 40, 187-191.

Miles, L. E. M., and Hales, C. N. (1968). Labelled antibodies and immunological assay systems. Nature, 219, 186.

Miranda, Q. R., Bailey, G. D., Fraser, A. S., and Tenoso, H. J. (1977). Solid phase enzyme immunoassay for Herpes Simplex Virus. J. infect. Dis., 136, Supplement, S304-310.

Miyai, K., Ishibashi, K., and Kumahara, Y. (1976). Enzyme linked immunoassay of thyrotropin. Clin. Chim. Acta, 67, 263-268.

Nairn, R. C. (1976). Fluorescent Protein Tracing, pp. 1-648. Churchill Livingstone, Edinburgh and London.

Nakane, P. K., and Kawaoi, A. (1974). Peroxidase labelled antibody. A new method of conjugation. $J$. Histochem. Cytochem., 22, 1084-1091.

Nassau, E., Parsons, E. R., and Johnson, G. D. (1976). The detection of antibodies to Mycobacterium tuberculosis by microplate enzyme-linked immunosorbent assay (ELISA). Tubercle, 57, 67-70.

Ogihara, T., Miyai, K., Nishi, K., Ishibashi, K., and Kumahara, Y. (1977). Enzyme labelled immunoassay for plasma cortisol. J. clin. Endocrinol. Metab., 44, 91-95.

Pesce, A. J., Mendoza, N., Boreisha, I., Gaizutis, M. A., and Pollak, V. E. (1974). Use of enzyme-linked antibodies to measure serum anti-DNA antibody in systemic lupus erythematosus. Clin. Chem., 20, 353-359.

Rubenstein, K. E., Schneider, R. S., and Ullman, E. F. (1972). Homogeneous enzyme immunoassay. A new immunochemical technique. Biochem. Biophys. Res. Comm., 47, 846.

Ruitenberg, E. J., Amstel, J. A., Brosi, B. J. M., and Steerenberg, P. A. (1977). Mechanisation of the ELISA for large scale screening. J. immunol. Methods, 16, 351-359.

Ruitenberg, E. J., Steerenberg, P. A., Brosi, B. J. M., and
Buys, J. (1976). Reliability of ELISA as control method for the detection of Trichinella spiralis infections in conventionally raised pigs. J. immunol. Methods, 10, 67-83.

Ruitenberg, E. J., and Buys, J. (1977). Application of the enzyme-linked immunosorbent assay (ELISA) for the serodiagnosis of human African trypanosomiasis (sleeping sickness). Amer. J. trop. Med. Hyg., 26, 31-36.

Russell, H., Facklam, R. R., and Edwards, L. R. (1976). Enzyme-linked immunosorbent assay for streptococcal M protein antibodies. J. clin. Microbiol., 3, 501-505.

Sadeh, D., Herszfeld, D., and Hexter, C. S. (1976). An enzyme immunoassay for human placental lactogen. Protides of the Biological Fluids, edited by H. Peeters, 24, 759-762. Pergamon Press, Oxford.

Saunders, G. C., Clinard, E. H., Bartlett, M. L., and $\stackrel{\omega}{ }$ Sanders, W. M. (1977). Application of the indirect is enzyme labelled antibody microtest to the detection and ir surveillance of animal disease. J. infect. Dis., 136, ㄱ Supplement, S258-266.

Saunders, G. C., and Wilder, M. E. (1974). Disease screening with enzyme labelled antibodies. J. infect. Dis., 129, 362-364.

Scherrer, R., and Bernard, S. (1977). Application of enzyme linked immunosorbent assay (ELISA) to the detection of calf rotavirus antibodies. Ann. Microbiol., $\infty$ 128A.

Schinski, V. D., Clutter, W. C., and Murrell, K. D. (1976). Enzyme and ${ }^{125}$ I-labelled anti-immunoglobulin assays in the immunodiagnosis of schistosomiasis. Amer. J. trop. Med. Hyg., 25, 824-831.

Schmitz, H., Doerr, H. W., Kampa, D., and Vogt, A. (1977). Enzyme immunoassay for cytomegalovirus antibody. J. clin. Microbiol., 5, 629.

Schuurs, A. H. W. M., and van Weemen, B. K. (1977). Enzyme immunoassays. Clin. Chim. Acta, 81, 1-40.

Smith, J., Holmgren, J., Ahlstedt, S., and Hanson, L. A. (1974). Local antibody production in experimental pyelonephritis. Infect. Immunol., 10, 411.

Sonksen, P. H. (1974). Radioimmunoassay and saturation analysis. Brit. Med. Bull., 30, 1-103.

Stiffer-Rosenberg, G., and Fey, H. (1977). Messung von tetanus-antitoxin mit dem enzyme linked immunosorbent assay (ELISA). Schweiz. med. Wschr., 107, 1101-1104.

Stimson, W. H., and Sinclair, J. M. (1974). An immunoassay for a pregnancy associated alpha-macroglobulin using antibody enzyme conjugates. FEBS Letters, 47 , N 190-192.

Theakston, R. D. G., Lloyd-Jones, M. J., and Reid, H. A. (1977). Micro-ELISA for detecting and assaying snake venom and venom antibody. Lancet, 2, 639-641.

Thraenart, O, and Kuwert, E. K (1977) Enzym immunoassay for demonstration of rabies-virus antibodies after immunization. Lancet, 2, 399-400.

Ukkonen, P., Koistinen, V., and Penttinen, K. (1977). Enzyme immunoassay in the detection of Hepatitis B surface antigen. J. Immunol. Methods, 15, 343-353.

van Weemen, B. K. (1974). Enzyme immunoassay. Doctoral thesis, pp. 1-151. Rijksuniversiteit Groningen, Holland.

van Weemen, B. K., and Schuurs, A. H. W. M. (1971).

\section{.}


Immunoassay using antigen-enzyme conjugates. FEBS Letters, 15, 232-236.

van Weemen, B. K., and Schuurs, A. H. W. M. (1972). Immunoassay using Hapten-enzyme conjugates. FEBS Letters, 24, 77-81.

van Weemen, B. K., and Schuurs, A. H. W. M. (1974). Immunoassay using antibody-enzyme conjugates. FEBS Letters, 43, 215-218.

van Weemen, B. K., and Schuurs, A. H. W. M. (1975). The influence of heterologous combinations of antiserum and enzyme labelled oestrogen on the characteristics of oestrogen enzyme immunoassays. Immunochemistry, 12, 667.

van Weemen, B. K., and Schuurs, A. H. W. M. (1976). Sensitivity and specificity of Hapten enzyme immunoassays. 1st International Symposium on Immunoenzymatic Techniques. INSERM Symposium No. 2, edited by Feldmann et al., pp. 125-133. North Holland Publishing Co., Amsterdam.

Vandervelde, E. M., Cohen, B. J., and Cossart, Y. E. (1977). An enzyme linked immunosorbent assay test for hepatitis B surface antigen. J. clin. Path., 30, 714-716.

van Hell, H., Bosch, A. M. G., Brands, J. A. M., van Weemen, B. K., and Schuurs, A. H. W. M. (1976). Pregnancy monitoring with enzyme-immunoassays for human placental lactogen and total oestrogens. $Z$. Analyt. Chem., 279, 143.

Veldkamp, J., and Visser, A. M. (1975). Application of the enzyme linked immunosorbent assay (ELISA) in the serodiagnosis of syphilis. Brit. J. vener. Dis., 51, 227-231.

Vestergaard, B. F., Grauballe, P. C., and Spangaard, H. (1977). Titration of Herpes Simplex virus antibodies in human sera by the enzyme linked immunosorbent assay (ELISA). Acta path. microbiol. Scand., Section B, 85, 466-468.

Voller, A., and Bidwell, D. E. (1975). A simple method for detecting antibodies to rubella. Brit. J. exp. Path., 56, 338-339.

Voller, A., and Bidwell, D. E. (1976). Enzyme immunoassays for antibodies in measles, cytomegalovirus infections and after rubella vaccination. Brit. J. exp. Path., 57, 243-247.

Voller, A., Bidwell, D. E., Huldt, G., and Engvall, E. (1974). A microplate method of enzyme linked immunosorbent assay and its application to malaria. Bull. Wld Hlth Org., 51, 209-211.

Voller, A., Huldt, G., Thors, C., and Engvall, E. (1975a). New serological test for malaria antibodies. Brit. med. J., 1, 659-661.

Voller, A., Draper, C. C., Bidwell, D. E., and Bartlett, A. (1975b). Microplate enzyme linked immunosorbent assay for Chagas Disease. Lancet, 1, 426-427.

Voller, A., Bidwell, D. E., and Bartlett, A. (1975c). A serological study on human Trypanosoma rhodesiense infections using a micro-scale enzyme linked immunosorbent assay. Tropenmed. Parasit., 26, 247-251.

Voller, A., Bartlett, A., Bidwell, D. E., Clark, M. F., and Adams, A. W. (1976a). The detection of viruses by enzyme linked immunosorbent assay (ELISA). J. gen. Virol., 33, 165-167.
Voller, A., Bidwell, D. E., and Bartlett, A. (1976b). Microplate enzyme immunoassays for the immunodiagnosis of virus infections. In Manual of Clinical Immunology, Chapter 69, edited by $\mathbf{N}$. Rose and $\mathrm{H}$. Friedman, pp. 506-512. American Society for Microbiology.

Voller, A., Bidwell, D. E., and Bartlett, A. (1976c). Enzyme immunoassays in diagnostic medicine: Theory and practice. Bull. Wld Hlth Org., 53, 55-65.

Voller, A., Bartlett, A., and Bidwell, D. E. (1976d). Enzyme immunoassays for parasitic diseases. Trans. R. Soc. trop. Med. Hyg., 70, 98-106.

Voller, A., Bidwell, D. E., Bartlett, A., Fleck, D. G., Perkins, M., and Oladehin, B. (1976e). A microplate enzyme immunoassay for toxoplasma antibody. J. clin. Path., 29, 150-153.

Voller, A., Bidwell, D. E., and Bartlett, A. (1977a). The Enzyme Linked Immunosorbent Assay (ELISA). pp. 24-26. Flow-line Publications, Guernsey.

Voller, A., Bidwell, D. E., Bartlett, A., and Edwards, R. (1977b). A comparison of isotopic and enzyme immunoassays for tropical parasitic diseases. Trans. $R$. Soc. trop. Med. Hyg., 71, 431-437.

Wallen, W. C., Mattson, J. M., and Levine, P. H. (1977). Detection of soluble antigen of Epstein Barr virus by the enzyme linked immunosorbent assay. J. infect. Dis., 136, Supplement, S324-328.

Walls, K. W., Bullock, S. L., and English, D. K. (1977). Use of the enzyme linked immunosorbent assay (ELISA) and its micro-adaptation for the serodiagnosis of toxoplasmosis. J. clin. Microbiol., 5, 273-277.

Warren, R. C., Bartlett, A., Bidwell, D. E., Richardson, M. D., Voller, A., and White, L. O. (1977). Diagnosis of invasive candidosis by enzyme immunoassay of serum antigen. Brit. med. J., 1, 1183-1185.

Watson, D. (1976). Correspondence. ELISA, a replacement for radioimmunoassay? Lancet, 2, 570.

Weltman, J. K., Frackelton, A. R., Szaro, R. P., and Rotman, B. (1976). A galactosidase immunosorbent test for human immunoglobulin E. J. Allergy, 58, 426-431.

Wolters, G., Kuijpers, L., Kacaki, J., and Schuurs, A. H. W. M. (1976). Solid phase enzyme-immunoassay for detection of hepatitis B surface antigen. J. clin. Path., 29, 873-879.

Wolters, G., Kuijpers, L. P. C., Kacaki, J., and Schuurs, A. H. W. M. (1977). Enzyme linked immunosorbent assay for hepatitis B surface antigen. J. infect. Dis., 136, Supplement, S311-317.

World Health Organisation. (1976a). The enzyme linked immunosorbent assay (ELISA). Bull. Wld Hlth Org., 54, 129-139.

World Health Organisation. (1976b). Parallel evaluation of serological tests applied in African trypanosomiasis: a WHO collaborative study. Bull. Wld Hlth Org., 54, 141-147.

Yolken, R. H., Kim, H. W., Clem, T., Wyatt, R. G., Kalica, A. R., Chanock, R. M., and Zapikian, A. Z. (1977a). Enzyme linked immunosorbent assay (ELISA) for detection of human reovirus like agent of infantile gastroenteritis. Lancet, 2, 263-266.

Yolken, R. H., Greenberg, H. B., Merson, M. H., 
Bradley Sack, R., and Kapikian, A. Z. (1977b). An ELISA for detection of $E$. coli heat labile enterotoxin. J. clin. Microbiol. (In press.)

Yorde, D. E., Sasse, E. A., Wang, T. Y., Hussa, R. O., and Garancis, J. C. (1976). Competitive enzyme linked immunoassay with use of soluble enzyme/antibody immune complexes for labelling. I. Measurement of human choriogonadotropin. Clin. Chem., 22, 13721377.

Requests for reprints to: Dr A. Voller, Senior Lecturer, Nuffield Laboratories of Comparative Medicine, Institute of Zoology, The Zoological Society of London, Regent's Park, London NW1 4RY.

Reports and Bulletins prepared by the Association of Clinical Biochemists The following reports and bulletins are published by the Association of Clinical Biochemists. They may be obtained from The Publishing Department, British Medical Journal (ACB Technical Bulletins), B.M.A. House, Tavistock Square, London WC1H 9JR. Overseas readers should remit by British Postal or Money Order.

SCIENTIFIC REVIEWS (price $£ 1 \cdot 00 / \$ 2.00$ each)

1 The assessment of thyroid function March 1971 F. V. FLYNN and J. R. HOBBS

2 Renal function tests suitable for clinical practice January 1972 F. L. MITCHELL, N. VEALL, and R. W. E. WATTS

3 Biochemical tests for the assessment of fetoplacental function May 1975 C. E. WILDE and R. E. OAKEY

4 Test of exocrine pancreatic function March 1977 A. H. GOWENLOCK

TECHNICAL BULLETINS (price $£ 1 \cdot 00 / \$ 2.00$ each)

22 Bilirubin standards and the determination of bilirubin by manual and technicon AutoAnalyzer methods January 1971 BARBARA BILLING, RUTH HASLAM, and N. WALD

23 Interchangeable cells for spectrophotometers and fluorimeters September 1971 s. S. BROWN and A. H. GOWENLOCK

24 Simple tests to detect poisons March 1972 B. w. MEADE $e t$ al.

25 Blood gas analysers May 1972 K. DIXON

26 Kits for enzyme activity determination September 1972 S. B. ROSALKI and D. TARLOW

27 Assessment of pumps suitable for incorporation into existing continuous flow analytical systems November 1972 A. FLECK $e t$ al.
28 Routine clinical measurements of transferrin in human serum September 1973 K. DIXON

29 Control materials for clinical biochemistry (5th edition) September 1973 J. F. STEVENS

30 Notes on the quality of performance of serum cholesterol assays September 1973 S. S. BROWN

31 Determination of uric acid in blood and in urine July 1974 R. W. E. WATTS

32 A survey of amino acid analysers readily available in the United Kingdom September 1974 J. E. CARLYLE and P. PURKISS

33 Definitions of some words and terms used in automated analysis November 1974 A. FLECK, R. ROBINSON, S. S. BROWN, and J. R. HOBBS

34 Measurement of albumin in the sera of patients January 1975 LINDA SLATER, P. M. CARTER, and J. R. HOBBS

35 Investigation of the validity of temperature correction factors for serum aspartate and alanine transaminases March 1975 s. B. ROSALKI et al.

36 Factors influencing the assay of creatinine November 1975 J. G. H. COOK

37 A survey of enzyme reaction rate analysers readily available in the United Kingdom July 1977 R. A. SAUNDERS and R. F. BURNS

38 Transport of specimens for clinical chemistry analysis November 1977 P. WILDING, J. F. ZILVA, and C. E. WILDE 